\title{
新たな査読制度の試み
}

\section{Peer review on trial}

Nature vol. 441(668)/ 8 June 2006

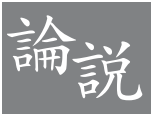

Nature が手がける新たな 2 つオンライン手法について

Nature という雑誌を作るにあたって私たちは、自らが主体 的に取材した記事や執筆を依頼した原稿の編集を、責任を もって行うことの大切さを常に意識している。と同時に、 新しい方法の模索にも常に積極的でありたいとの思いから、 今回はオンラインのもつ双方向性を最大限に活用するべく、 原則ぎりぎりのところで可能性を探ろうと考光た。

その1つとして最近、news@nature.comのサイトで更新 を行っている日々の科学ニュース記事にブログをつける試みを 始めた。成果例としてはすでに、生物進化における「ミッシ ングリンク」を埋めるとされる Tiktaalik roseae あぐって起 きた議論などが挙げられる (http://blogs.nature.com/news/ blog/2006/04/the_fish_that_crawled_out_of_t.html 参照)。

ブログがジャーナリズムにとって代わる可能性は低いが、 ブログは今後も抬そらくジャーナリズムを補完する形で貴重 な役割を果たしていくだろう。そしてこれよりもさらに成り 行きの読めないのが、Nature でスタートさせた一種の公開 査読制度の試験運用がもたらす結果である。この試験運用に 伴って、查読に関する一般参加のオンライン討論も行われる (www.nature.com/nature/peerreview/index.html 参照)。

数か月を予定している試験運用の期間中、Natureでは従 来どおりの査読方法、つまり全投稿論文のうち編集部が選 んだ論文を通常 2 人か 3 人の専門家に送って行う匿名査読 も継続していく。私たちは、現行のこの查読方法はうまく いっていると考光ている。だが一方で、6月上旬から数週 間にわたって行うウェブ上での議論では、そのほかの査読 方法の可能性を探り、また従来の科学誌がもつさまざまな 機能をオンラインで展開できるような技術の可能性、それ に査読の倫理性などについても問いたいと思う。

オンラインで公開査読を行うという今回の試験運用により、 投稿論文の著者は希望に応じて、現行の查読方法と共に両方 の查読を並行して受けることができるようになる。查読に迴 されることが決まった投稿論文には今後もすべて、まずは従 来のプロセスが適用される。そのうえで著者は、投稿論文の 原稿を公開のウェブサイト上に揭載することにも同意できる。 その論文原稿に対してはその後、氏名を明らかにすることを
条件に、誰でもオンライン上でコメントを寄せることが可能 となる。そして、Nature の編集者があらかじめ依頼しておい た匿名査読者のコメントをすべて受け取った時点で、公開ウェ ブサイトに扔けるコメントの受け付けを締め切り、提出され たすべての意見に対し、編集者と著者で検討していく。

この公開手順は、投稿論文の初稿にのみ適用される。論 文原稿の受理・不受理がいったん決まった後は、公開ウェ ブサイトに寄せられたコメントを編集者が閉鎖的プロセス で評価していく。

試験運用は数か月にわたって行われる。該当する論文原稿 に関する最終決定がすべて完了した時点で、Nature は受け 取ったコメントを全体的に評価し、同時にそれらのコメント を正当に扱うために必要となる作業について検討を行う予定 だ。その結果はNature 誌上で報告し、現在の查読手順を適 切に変更すべきかぞうかを考光たい。現時点では、その変更 は抢そらく Nature の既存のプロセスを補完するものにとど まり、代替するものにまではならないと予想している。

今回は熟慮のうえ、「実験」ではなく「試験運用」という言 葉を使うことにした。実験となれば、公開査読に取り組む根本 的なメリットとデメリットを明らかにする必要があるが、私た ちはそこまでの大それた野望をもっているわけではない。ただ、 新しい方法がぞうなるのかを探りたい。論文著者を対象に行つ た最近の調査でも、この新しい考方方には十分な関心が得ら れ、試験運用をするだけの価值のあることが示されている。

Nature の公開ウェブサイトに揭載してコメントを受けつけ る論文は当然、一般にアクセスする人々やジャーナリストに よる格好の批判対象となるだろう。メディアによる先行報道 は論文の受理に際して不利にはならない。しかし、查読を受 けていない論文にはそれなりのリスクがある点は、ジャーナ リストも提い扔い理解していくことになるはずだ。

Nature および発行元出版社では今回も、これまでと同様、 オンラインのもつ可能性を探り、それを拡大しようとしている。 しかし、私たちが核として揭げる目標に変わりはない。すなわち、 自分たちの編集技能によって提供できるかぎりに拀いて、今後 も最も刺激的なコンテンツを読者に届けていくことである。 